\title{
Performance Monitoring and Evaluation in Botswana's Public Service: Achievements and Challenges
}

MPABANGA, Dorothy

Abstract

he paper aims to explore the
implementation of performance monitoring and evaluation tools used in Botswana's public service. The paper also identifies achievements and challenges of implementing performance monitoring and evaluation system and suggests ways for improvement. This paper uses secondary data sources. The paper reveals lack of performance monitoring and evaluation skills, poor supervision, poor conditions of service and a poor work ethic as some of the factors contributing to ineffective use of performance monitoring and evaluation tools in the service. Leadership commitment and support, benchmarking reforms, training and education, developed administrative and governance structures as well as welldefined public policy and program formulation and implementation processes are some of the success factors to enhanced performance management and evaluation systems in Botswana. The paper argues for adoption of a developmentalled model in order to enhance existing performance monitoring and evaluation system that would improve implementation of government policies and programs. Botswana has been striving to excel in service delivery through performance monitoring and evaluation oriented reforms.

Keywords: performance management systems, performance appraisal, performance reward, balanced score card, motivation. 
Performance Monitoring and Evaluation in Botswana's Public Service 51

\section{Introduction}

Performance monitoring and evaluation tools have been viewed as one of the key measures designed and adopted to enhance performance of individuals, teams and the organisation in general (Armstrong 2009). Governments around the world have over the years adopted and applied multiple public sector reform initiatives in order to enhance service delivery to citizens and improve implementation of public policy and programmes. The Botswana government has not been left behind in attempts to reform and re-invent the public service (Hope, 1995; Republic of Botswana, 2003). It is against this background that this article explores performance monitoring and evaluation systems in Botswana's public service, identifies achievements and success factors, examines appraisal problems and suggest approaches to improve the existing performance review process. One of the major research questions is firstly to explore the effectiveness of performance monitoring and appraisal tools, secondly to identify problems or challenges associated with the application of performance monitoring and appraisal methods, thirdly to assess success factors and lastly to suggest ways or approaches to improve the existing performance monitoring and appraisal methods in Botswana's public service.

This paper used secondary sources and documented analysis of existing performance monitoring and evaluation methods in Botswana's public service. The article will commence by highlighting the conceptual framework on performance monitoring and evaluation, followed by reviewing literature on performance monitoring and evaluation process and methods. The second part will explore performance monitoring and evaluation systems in the context of Botswana, as well as identify achievements and assess challenges faced when monitoring and evaluating performance in the public service. The last section will suggest new approaches to enhance existing performance monitoring and evaluation system in Botswana's public service.

\section{Conceptual and Theoretical Frameworks of Performance Monitoring and Evaluation}

According to Cole (2011:300) performance appraisal is a systematic approach that entails a planned process to assess individual performance and commences with completing a form, conducting an interview, discussion of progress, results and agreeing on action. Performance appraisal can take the form of a rational theory of management and 
emotional intelligence which sets the appraisal system in motion (Cole, 2011). Thurston Jr. and McNall (2010:202) assert that performance appraisal could be guided by the traditional-rational and political perspectives which emphasise testing and measuring performance against set standards on the assumptions that appraisal is more about personalities, self-interest, power and negotiations. Performance appraisal is based under Theory X which was advocated by McGregor (1960) (in Cole, 2011:301) and this is a management style which assumes that people are unreliable, unable to take responsibility and need close supervision and control. Cole further asserts that the performance appraisal model is based on a cyclical process entailing setting of performance standards which are assessed against set standards or criteria. Cole questions the accuracy and fairness of such a performance appraisal system which is based on control. Bratton \& Gold (2007:287) point to the three models of performance appraisal based on a performance control approach as shown in the diagram below.

Figure 1: Performance control approach to appraisal

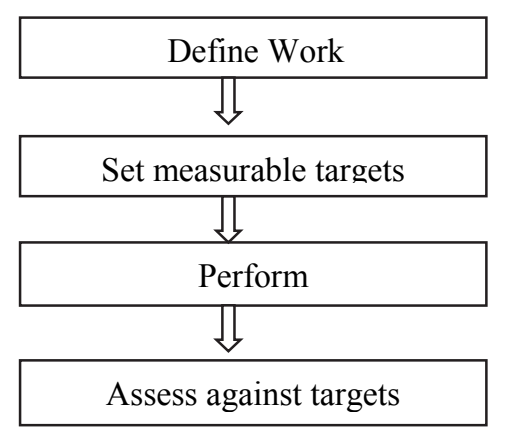

Source: Bratton \& Gold, 2007:287. (Adapted from Randell, 1994).

The Bratton \& Gold (2007) assert that there is a shift to developmental approach which emphasised the view that it is important to harness peoples' potential and future development. The transformational process model emerged as an approach that measures output and behaviour (Bratton \& Gold, 2007:290), as demonstrated in figure 2 below. 
Figure 2: Transformational process model

\begin{tabular}{|l|l|l|l|}
\hline $\begin{array}{l}\text { Means } \\
\text { Knowledge } \\
\text { Attributes } \\
\text { Attitude }\end{array}$ & $\begin{array}{l}\text { Transformational } \\
\text { process } \\
\text { Behaviour applied to } \\
\text { task }\end{array}$
\end{tabular}$>$\begin{tabular}{l}
$\begin{array}{l}\text { Ends } \\
\text { Results } \\
\text { Measurements } \\
\text { Standards }\end{array}$ \\
\hline
\end{tabular}

Source: Bratton \& Gold, 2007:290

Nel, Werner, Poisat, Sono, Du Plessis \& Ngalo (2011:411) assert that the evaluation of employee performance can be based on two perspectives entailing the rational perspective which assumes that the value of each employee can be estimated and that the goal of appraisal is accuracy where supervisors and workers are passive in the process and workers' performance is clearly defined. On the other hand, the political perspective assumes that the goals of appraisal is utility and depends on the agenda or goals of the supervisor and what is being assessed is ambiguous (Ibid). According to Rowland \& Hall (2013) performance appraisals have evolved from subjective appraisals to more objective, integrative approaches that incorporate employee wellbeing and have become a more strategic part of the human resource management function.

Thurston Jr. \& McNall (2010) assert that performance appraisal can be founded on the conceptual framework associated with the organisational justice theory where justice perceptions related to attitudes and behaviour that affect reaction to appraisal ratings. In this case those appraised would react to an appraisal depending on their perceptions regarding fairness in the appraisal procedure. The due process model is premised on procedural fairness perceptions regarding treatment during the appraisal, allocation of rewards and decisions made (Ibid). This model could be applied to result in a shared view in the acceptance of performance standards which will be compared with actual performance during the appraisal process (Thurston Jr. \& McNall, 2010:202). The two authors further said that the exchange theory could be used to incorporate aspects of the justice theory which entail procedural justice, interactional justice, interpersonal justice and information justice.

Rowland \& Hall (2013:197) also mention a variety of frameworks to explain appraisals including the theory of distributive justice, the equity theory and the social sciences framework which could be useful to explain organisational approaches to performance 
management. Thurston Jr. \& McNall (2010) assert that the equity theory, which relates to the economic exchange relationship, is based on the perception of equity and fairness in the distribution of outcomes from an appraisal process (Adams, 1963; Homans, 1961, (in Thurston Jr. \& McNall, 2010:205). The two authors suggest that an appraisal would be perceived as fair if the rater is trying to motivate, develop an employee, and considered unfair if the rater tries to avoid conflict, uses favouritism or has a political agenda. They assert that performance appraisals are more than objectives, judgements, evaluations and interviews that are emphasised by the traditional and political models. Rowland \& Hall (2013) suggested that objectives of performance appraisals should incorporate concepts of distributional justice and a wider ethical framework as perceptions on inequity impact on commitment and performance.

\section{Literature on Performance Monitoring and Evaluation}

According to Ahmed, Sultana, Paul \& Azeem (2013) performance evaluation is part of the human resource function concerned with helping organisations improve performance and at the same time help improve individual performance. Furthermore, performance evaluations are used to track individual performance against organisational goals, as well as to identify individual strengths and opportunities for future improvements. Mathis \& Jackson (2000:384) posit that 'performance appraisal is the process of evaluating how well employees are doing their jobs as compared to a set standard and then communicating that information'. The two authors assert that such appraisals also have been called employee rating, employee evaluation, performance review, and performance evaluation and results appraisals (Ibid; 384). Dessler (2005:310) defines performance appraisal as an evaluation of employee's current or past performance relative to his or her performance standards. Sherman, Bohlander \& Chruden (1988:255) assert that the 'traditional term merit rating has generally been superseded by such terms as performance appraisal and performance evaluation.' The authors suggest performance appraisal starts with gathering information about performance and this information will be evaluated in the context of organizational needs and communicated to the individual for high levels of performance. According to Pigors \& Myers (1977) performance appraisal was adopted by many organisations to help supervisors evaluate the work of each employee. They further asset that a system of performance evaluation and review can be one method of assessing job performance (Pigors \& Myers, 1977:279). Robins, 
Decenzo \& Coulter (2011:169) define a performance management system as a system of establishing performance standards that are used to evaluate individual performance. Cole (2011) asserts that it is the manager's responsibility to ensure that results are obtained from all resources and are monitored accordingly.

Performance appraisal is a planned and continuous process which involves multiple stakeholders including performance rating by the immediate supervisor, team member, peers or co-workers, external customers, 360-degree feedback as well self-appraisals (Armstrong 2006:639; Mathis and Jackson 2000:392; Nel, Werner, Poisat, Sono, Du Plessis \& Ngalo; 2011:411 \& 388). Nel et al., (2011) pointed out that performance evaluation depends on the evaluation techniques selected to measure performance and the rater who is charged with observing and rating performance. Peer rating could be good though they could be clouded by friendship bias while self-appraisals are good for counselling and self-development and minimise defensiveness (Nel, et al., 2011:412). According to Mathis \& Jackson (2000:384 \& 362) performance standards define expected levels of performance, for instance explains what is exceptional, excellent, satisfactory and unsatisfactory performance. The authors further assert that these standards are set before work is done and later rated after work has been done. As stated by the two authors, performance appraisal plays multiple roles including administrative role where appraisals could be used for compensation, promotion, dismissal, lay off, development role where reviews are for identifying training and development needs, career planning and strengths and areas for growth. Bratton \& Gold (2007:284) identified appraisal uses to include improving morale and motivation, clarify expectations, determine rewards, improve communication and discipline and counselling; setting goals and targets as well as planning remedial actions.

\section{The Performance Monitoring and Evaluation Process}

As mentioned above, performance appraisal forms part of the human resource management function which serves the purpose of developing capacity of people to meet and exceed expectations (Armstrong, 2006:639). As shown in figure 3 below, Armstrong points out that performance management and appraisal are planned and continuous processes which entail performance development and agreement, measurement, feedback, positive re-enforcement and dialogue. The planning stage involves establishing performance standards and expectations, setting objectives and 
targets and agreeing on assessment methods or measures, establish feedback mechanisms as well as development of personal development plans. As suggested by Cole (2008:305) it is important to make performance appraisal criteria to be specific, measurable, achievable; relevant and timed (SMART). Armstrong (2006) identified the second stage to entail managing performance throughout the year, where there is continuous monitoring, feedback and corrective action taken on performance. The fourth stage is the actual performance review or appraisal where a formal evaluation is carried out once or twice a year. This is the stage where performance is evaluated against set standards and targets and a rating is awarded using different performance rating techniques (Armstrong, 2006:640). Armstrong further states that performance management is based on the goal setting theory which stimulates effort and challenge people to use skills and knowledge, (Latham \& Locke 1979, (in Armstrong, 2006:620), control theory which focuses on feedback and corrective action and social cognitive theory which is based on self-efficacy concept of what people believe they can do (Bandura 1986, (in Armstrong, 2006:621).

Figure 3: Performance Management Cycle
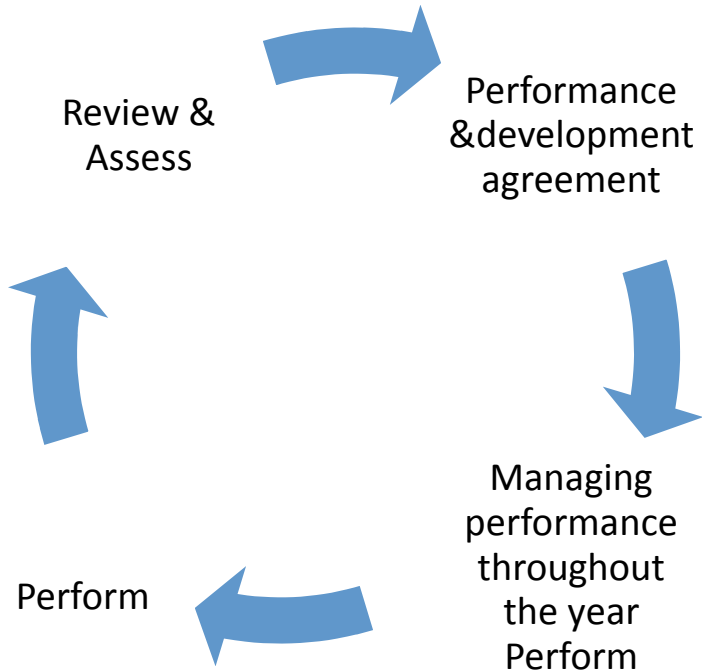

Source: Armstrong, 2006:639 
On the overall, the performance appraisal process starts with the immediate supervisor and others rating the employee, the supervisor compiling a report and forward it to the hums resource department to review rating results and reward performance in terms of promotion, salary increase, training and development (Armstrong 2006:639, Mathis and Jackson, 2000:392; Nel, Werner, Poisat, Sono, Du Plessis \& Ngalo, 2011:411 \& 388). Mathis \& Jackson (2000:389) posits that human resource departments are responsible to design appraisals, ensure appraisal are carried out, coordinate the appraisal process and ensure that supervisors are trained on the appraisal process. The 2 authors further assert that supervisors are responsible for evaluating and reviewing planned and actual performance, give constructive feedback and rate performance according to set and agreed scale, review appraisal with employee (twoway communication), prepare and submit appraisal report to HR department for action. Mathis \& Jackson (2000) are of the view that there are no set appraisal methods or one best way of appraisals, it depends on what the organization wants to achieve. A combination of methods would enhance performance evaluations combined with clear standards and purpose of appraisals as well as training of managers and support and guidance of top management. The discussion on the techniques of performance appraisals follows.

\section{Techniques of Performance Monitoring and Evaluation}

As shown in the diagram below, there are various techniques or methods that organizations could use to monitor, measure, evaluate and appraise employee performance. Depending on the type of method and rating scale the organization selects, the rating can be based on performance rated on actual tasks or roles performed over time, on behaviours, personality attributes required to help achieve planned objectives and targets for example teamwork, communication, interpersonal skills as well as performance results or outcomes (Mathis \& Jackson, 2000; Bratton \& Gold, 2007:302). As pointed out by Nel, Werner, Poisat, Sono, Du Plessis \& Ngalo (2011) there is need to plan performance and determine who is going to be engaged in the performance measurement process and decide on the evaluation method. They further affirm that the success of performance evaluation depends on the person who is going to carry out the appraisal and the method used for appraisal and that evaluation methods should take 
into account the strategic direction of the organization and the developmental aspects of an employee.

Figure 4: Types of Appraisal

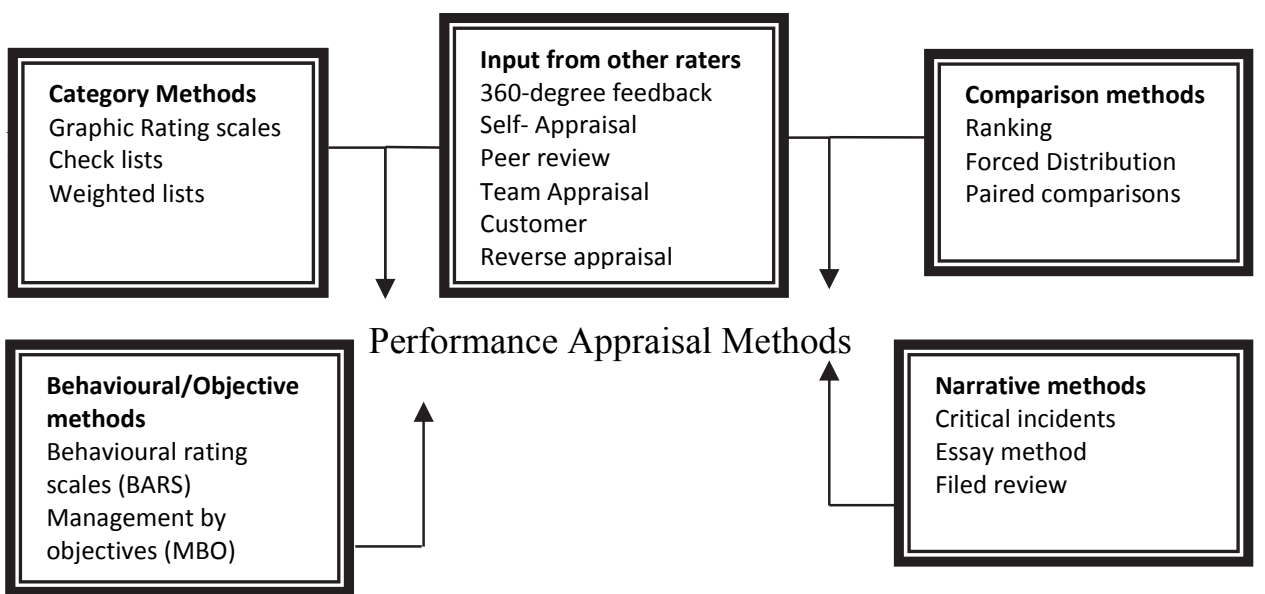

Source: Mathis \& Jackson, 2000:393; Nel et al., 2011:405

In addition to the above, performance appraisal methods include balanced score card as advocated by Kaplan \& Norton (1996) (in Olve, Roy, \& Wetter, 2000) which is a modern management and measurement tool that applies four perspectives in terms of managing and measuring performance at individual and organizational level. The four perspectives used to measure and evaluate performance entail the financial, customer, internal processes and learning and growth, as shown in the diagram below. As pointed by Prowse \& Prowse (2009:71), the use and introduction of techniques such as the score card extended performance measures and evaluation to include feedback on internal processes, learning and growth. The main component of a score card is that it gives a holistic approach to measuring and monitoring performance on how the employees and organization is doing in terms of finances, customers, internal processes, learning, growth and innovation. However as noted by Armstrong \& Baron (1998:242) the proponents of the score card point out that the scorecard cannot be used in isolation and has to be linked to other systems and processes in the organization such as goal setting programs, compensation and budgets. 
Figure 5: The four perspectives of a Balance Score Card

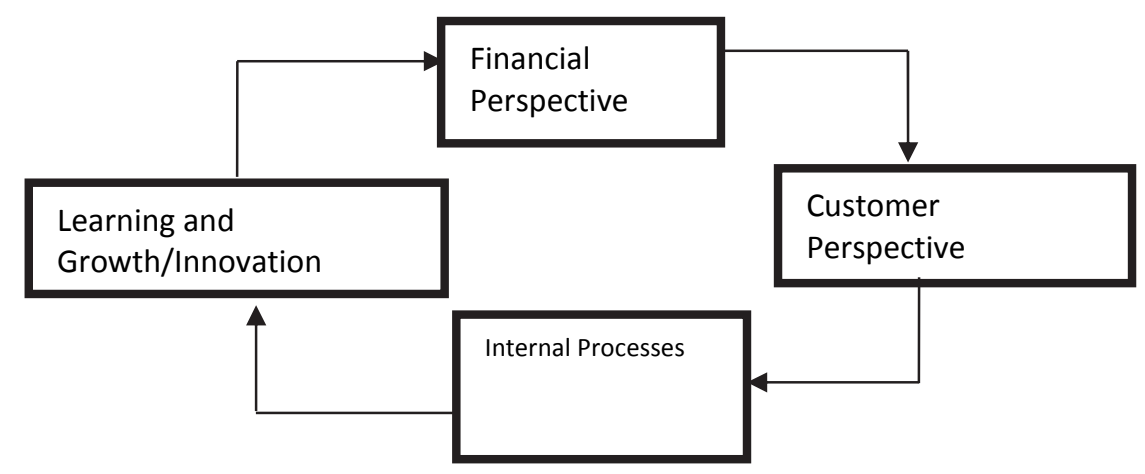

Source: Norton \& Kaplan, 1996 (in Olve, Roy, \& Wetter, 2000)

\section{Performance Rating Scales}

Different rating scales are used during the appraisal process including outstanding/exceptional, excellent, satisfactory and unsatisfactory performance (Mathis \& Jackson 2000; Bratton \& Gold (2007); Armstrong (2006). Table 1 below is an illustration of rating scales.

Table 1: Rating Scales

\begin{tabular}{|l|l|l|}
\hline \multicolumn{1}{|c|}{ Rating scales } & \multicolumn{1}{|c|}{ Rating } & \multicolumn{1}{c|}{ Forced distribution } \\
\hline Outstanding: & Exceeds expectations & Outstanding (10\%) \\
\hline Excellent: & Meets objectives & Very Good (20\%) \\
\hline Satisfactory: & Not meeting all objectives & $\begin{array}{l}\text { Satisfactory (40\%) } \\
\text { Marginal (20\%) }\end{array}$ \\
\hline Unsatisfactory: & $\begin{array}{l}\text { Fails to meet most objectives, lacks } \\
\text { commitment, lacks ability }\end{array}$ & Unsatisfactory (10\%) \\
\hline
\end{tabular}

Source: Mathis \& Jackson, 2000:396 \& 398; Armstrong, 2007:630 


\section{Problems with Appraisals}

Various authors have identified multiple problems associated with performance appraisals as shown in table 2 below.

\section{Table 2: Performance Appraisal Errors}

\begin{tabular}{|c|c|c|}
\hline Type of problem & Attribute & Suggestions to Improve \\
\hline Recency Effect & $\begin{array}{l}\text { Giving more weight to a recent } \\
\text { event }\end{array}$ & $\begin{array}{l}\text { Have frequent appraisals and } \\
\text { feedback. }\end{array}$ \\
\hline Central tendency & $\begin{array}{l}\text { Rating in the middle of the } \\
\text { scale, due to lack of appraisal } \\
\text { skills }\end{array}$ & $\begin{array}{l}\text { Train in appraisal skills, } \\
\text { counselling to find out why rate } \\
\text { average. }\end{array}$ \\
\hline Leniency/Strictness & $\begin{array}{l}\text { Being too generous/strict } \\
\text { leading to unfairness in rating. }\end{array}$ & $\begin{array}{l}\text { Make supervisors aware } \\
\text { (through counselling) of the } \\
\text { problem of leniency/strictness. }\end{array}$ \\
\hline Hallo effect & $\begin{array}{l}\text { Rating of one character affects } \\
\text { other ratings. }\end{array}$ & $\begin{array}{l}\text { Counselling to make supervisor } \\
\text { aware of the problem }\end{array}$ \\
\hline Rater's biasness & $\begin{array}{l}\text { Rater's values affect appraisal } \\
\text { process, resulting in unfair } \\
\text { rating (normally hidden) }\end{array}$ & Counselling. \\
\hline $\begin{array}{l}\text { Unclear } \\
\text { performance } \\
\text { standards }\end{array}$ & $\begin{array}{l}\text { Increase subjectivity of rating, } \\
\text { demotivating rating, }\end{array}$ & $\begin{array}{l}\text { Develop clear standards and } \\
\text { specific criteria to evaluate } \\
\text { performance. }\end{array}$ \\
\hline Inconsistent ratings & $\begin{array}{l}\text { Some managers lenient, } \\
\text { others very strict }\end{array}$ & $\begin{array}{l}\text { Counselling, mentoring, } \\
\text { coaching and training in } \\
\text { appraisals. }\end{array}$ \\
\hline $\begin{array}{l}\text { Biasness related to } \\
\text { gender, race, age } \\
\text { and ethnicity }\end{array}$ & $\begin{array}{l}\text { May be difficult to detect } \\
\text { because they are usually } \\
\text { hidden. }\end{array}$ & $\begin{array}{l}\text { Counselling may help to make } \\
\text { supervisor aware of the } \\
\text { problem. }\end{array}$ \\
\hline
\end{tabular}

Source: Mathis \& Jackson, 2000:402; Armstrong, 2006:632; Prowse \& Prowse (2009:71),

Nel et al., 2011:418.

Other problems of appraisal include rater playing god, and in the process intimidating employees, raters avoid giving constrictive criticism for fear of defensive behaviour from the appraise; personality biasness and not giving effective feedback to employees (Nel, Werner, Poisat, Sono, Du Plessis \& Ngalo, 2011:419). There have been suggestions that the above problems could be improved by training and development of managers by the HR department, support and commitment from top management, as well as using 
multiple appraisal methods to augment the performance management and the appraisal process (Nel, Werner, Poisat, Sono, Du Plessis \& Ngalo, 2011; Bratton \& Gold, 2007).

Ahmed et al., (2013:721) assert that organizations in some cases use multiple criteria for evaluating employee's performance and this makes the whole process complex as several rules apply for criterion. They suggest the use of fussy evaluation approach which reduces subjectivity associated with performance evaluation, this approach was developed by Pakdamar \& Guler (2008) and used by other researchers, for example Galinec \& Vidovic (2006); Baheshti \& Lollar (2008); Paladini (2009) (cited in Ahmed et al., (2013). Some of the major criteria or elements of the fussy model employee performance evaluation entail:

- Employee's knowledge of the job,

- Quality and quantity of work,

- Problem solving and decision making skills,

- Team work and cooperation,

- Leadership,

- Rate of absenteeism and late attendance

- Communication skills, time management

- Adaptability and flexibility

- Appearance and grooming

- Professional attitude

- Initiative and innovation

- Dependability

- Confidence

- Steadiness and pressure

- Ethics and integrity

- Planning capability and

- Versatility' (Ahmed et al., (2013:727).

The above factors or criteria in the fussy model of evaluating employee performance is said to address some of the subjectivity involved in other performance evaluation or appraisal methods. The fussy model suggests the use of input variables to determine the best performing employee in an organisation. Ahmed et al., (2013) argue that a different criteria or input variables can be used depending on the purpose for appraisal and 
results from this can be used to make a decision to train, promote or offer a performance bonus to employee with the highest scores. The main element of the model is the use of MATLAB software which processes selected inputs variables and produce output results indicating the level of employee performance (Ahmed et al., 2013:731)

According to Halachmi (2002:63) many countries are making efforts to enhance accountability and efficiently manage their resources by adopting performance measurement and new budgetary techniques such as performance budgeting, activity based costing and accrual-based accounting. Furthermore, Halachmi asserts that governments are enhancing their flexibility by adopting other reform measures such as inter and intra-governmental contracts, outsourcing and privatisation. Many countries including those in the commonwealth are moving towards the same direction by adopting new public administration techniques which emphasises role of public managers in providing high quality services, increasing managerial autonomy, provision of human and technical resources to enable managers meet their targets, and be receptive to the idea that some public responsibilities can be best performed by public or private or even the non-government sector (Halachmi, 2002:63). Halachmi further asserts that reforms are not only meant to improve government operations but are also introduced to help organisations gain competitive edge in order to create the much needed employment and other socio-economic opportunities for citizens so that in the long run the burden of government to take care of these people is reduced in the process.

Halachmi (2002) further posited that the United States of America reformed its government by adopting the Government Performance and Results (GPRA) Act of 1993 which was designed to re-invent a government that works better and costs less. The GPRA Act integrated elements of strategic planning, budgeting, management, performance monitoring and assessment into the process (Halachmi, 2002:67). The GPRA used a technique that analysed the strength, weaknesses, opportunities and threats (SWOT) and the outcome of the analysis were mission and vision statements, annual performance plans, indicators and targets. Halachmi noted that similar reforms to reinvent government were introduced in developed countries such as Australia, New Zealand, Sweden and many other OECD countries around the same time. Some of the good aspects of the GPRA in the USA for example were that it was used to evaluate past 
programs and use lessons to improve new activities. In addition, GPRA was accompanied by educating the media, public, legislators about the program and its benefits and this as pointed out by Halachmi (2002:71), was to make government more transparent and minimise the notion that government was arbitrary or deliberately wasteful.

\section{Performance monitoring and evaluations are 'a must do' for governments}

Hawke (2012:311) posit that performance management has been a formal part of the Australian public sector since 1984 when the government introduced the financial management improvement program. The performance management framework in Australia has been revised several times and entails prominent features including budget planning, preparation and execution based on outcome, performance measures, considerable flexibility to reallocate resources, devolution of responsibility and minimal intervention by central departments, Cabinet or the Parliament (Ibid, 311). The performance management has been subjected to periodic reviews and has revealed successes and challenges and these include poor quality of performance information, lack of broader societal engagement in the system and lack of connectedness. According to Prowse \& Prowse (2009) appraisals and performance management have been associated with employee reward ever since the development of strategic human resource management in the 1980s. The authors further acknowledge evidence from research showing the increasing use of merit pay based on performance appraisal in private and public sector organisation in the UK and USA (Prowse \& Prowse, 2009:74).

According to Rowland \& Hall (2013:195) appraisals have shifted from developmental to a performance focus, and perceived unfairness in both procedures and outcomes threatens to undermine commitment and sustainable performance. Performance appraisal can consist of pay-led systems where outcome of an appraisal can be a promotion, pay increases or actions to remedy a disciplinary issue, or it can be developmental led where appraisal can result in training and development (Armstrong \& Baron, 1997, in Rowland \& Hall (2013). Knippen \& Green (1995:29) assert that performance appraisal are not what employees expect or want as emphasis is normally 'on what you did not do or what you did wrong rather on accomplishment'. They suggest the following when dealing with an unfair appraisal.

- Allow a few days to pass to cool off. 
- Review how you are evaluated.

- Assess the method used.

- Review areas your boss concentrated on, for example favourable areas and less interest.

- Plan on areas where results are expected (use the SMART technique).

- List things you would like to achieve before your next appraisal.

- Set next appraisal date.

- Constructive feedback from both sides (accept part of the blame, don't be defensive.

- Strive for improvement.

- Agree on improvements for the next appraisal.

- Identify areas to concentrate on before the next appraisal.

- Positive re-enforcement, and

- Report back on progress' (Knippen \& Green, 1995:31).

\section{Challenges and complexities of performance monitoring and evaluation}

Zoe \& McGuire (2004) found out that performance management and measurement systems are filled with complexities. For example, two case studies in the United Kingdom's public sector revealed that performance is about measurement and evaluation and not management, that the system in the two case studies was not interactive, did not allow improvement targets, were not appropriately evaluated and there was overall lack of ownership (Zoe \& McGuire, 2004:259). As pointed out by Halachmi (2002:) the GPRA system introduced in 1993 in the USA to enhance performance management, measurement and reporting had some challenges including pressuring managers and employees to do the right thing for example to do what will give them higher rating, resistance to change, especially if it was viewed as a political tool, it required a lot of information and data thus creating pressure on federal agencies irrespective of size.

Findings from a study from two large organizations revealed that performance 'appraisal frequently creates actual and perceived unfairness/injustice in both procedures and rewards, and generates tensions between managing performance and encouraging engagement' (Rowland \& Hall, 2013:195). Rowland \& Hall (2013:198) state that research 
has demonstrated the ineffectiveness of appraisal and performance management schemes and evidence that support a positive relationship between appraisals-based extrinsic rewards and improvements in quality of performance. Many appraisal tools have served multiple purposes for example graphic rating scales, behavioural anchored rating sales, management by objectives and competency based appraisals systems and an excise which is normally carried out by line managers or immediate supervisors (Prowse \& Prowse, 2009; Rowland \& Hall, 2013).

Recent additions to appraisal tools include self-appraisals, peer appraisals and 360 degree appraisals which promote the idea that an appraisal that is inclusive of all contacts inside and outside the workplace will give a fair account of performance of an individual, team or organisation (Armstrong, 2006; Prowse \& Prowse, 2009). A score is another appraisal tool that uses four perspectives and evaluates performance from a financial, customer, processes and learning and growth as asserted by Norton \& Kaplan, 1996 (in Olve, Roy \& Wetter, 2000). E-appraisals are also used in some organisation and they form part of self-appraisals (Payne, 1996, in Rowland \& Hall 2013:198). Rowland \& Hall (2013) assert that appraisals are now moving away from subjective judgments and reward to employee development activates. As posited by Rowland \& Hall (2013) many organisations have shifted to strategic management of human resources and performance management have a pivotal role to play in helping organisations achieve strategic objectives through sustained performance and effectiveness.

Some of the findings by Rowland \& Hall (2013:201) were that on the overall, performance appraisals and performance related pay were associated with distrust and inequity of treatment between high and low producers. In addition, Rowland \& Hall research revealed that employees were strongly against performance related pay, and viewed them as unfair, while most viewed training opportunities as favours extended by managers and that there was resentment that rewards were given to undeserving individuals. Rowland \& Hall (2013:202) research supported the finding by others that appraisals were a necessary evil if they were conducted in a fair and systematic manner. The appraisal process was viewed as an administrative burden, a one-time exercise, which was not objective, riddled with flawed procedures and imposed by management.

Prowse \& Prowse (2009:71) identified multiple criticisms associated with monitoring and evaluating performance of individuals in organisations including untrained appraisers, central tendency effect, organisational politics, recency effect, tighter 
management control over professionals and staff and biasness related to gender and ethnicity. The two authors affirm inconsistent evidence from organisations on the impact of performance pay and its effectiveness in improving performance (Prowse and Prowse, 2009:74). As reported in Bach \& Sisson (2000:281) evidence that organisations have suspended or reviewing individual performance pay schemes because they have had produced no effect in performance or have even demotivated staff (in Prowse \& Prowse, 2009:74). The authors suggest enhanced training of assessors in interpersonal skills and increased use of 360-degree appraisal tool to monitor and evaluate employee feedback.

A study conducted by Radebe (2015) to evaluate managers' perceptions about the effectiveness of the implementation of performance appraisal in municipality in South Africa revealed that the appraisal systems were not effectively implemented due to a variety of factors. Radebe found that there was lack of mutual setting of performance criteria and objectives. Furthermore, the study revealed that the system was not linked to pay, promotion and career development of employees. Communication issues emerged as there were perceptions of lack of open communication and trust in the design and implementation of the appraisal system (Radebe, 2015:175).

The experience of Namibia of performance appraisal in the nursing profession has shown that there were problems and challenges. In a study conducted by Awases, Bezuidenhout \& Roos (2013:1) factors affecting performance appraisal of nurses included an absence of performance appraisal system, lack of recognition of high performing nurses and poor working conditions. There were positive factors that emerged from the research including an element of pride and commitment by the nursing profession studied despite these challenges.

The Kenya government introduced civil service reforms in 1993 and commenced with program review followed by performance management systems and efforts to enhance leadership, governance, staffing, training and financial management and compensation (Marwa \& Zairi, 2009:40). The authors argue that although reforms have had a positive impact in transforming the civil service in Kenya, there remain challenges in the areas of governance structures and there is need to use a holistic approach instead of using quick fix approach to creating excellence.

The Malaysian civil service introduced reforms mainly in the areas of human resource management and the move towards managing results (Siddiquee, 2010). Some of the reforms include an employee appraisal system where work output is directly linked to 
performance and it is based on cost, quantity, quality and time factors (Siddique, 2010:42 \& 44), while the budgetary reforms link inputs, outputs, performance indicators and results and these reforms have enhanced accountability. Siddique (2010) identified one of the weaknesses of reforms as lack of clearly defined input-output limited evaluation and an administrative system that retained centralised control despite the requirement for decentralisation under the results based management system. Siddique (2010:47) further posits that managing for results requires effective monitoring of performance. However, agencies are reluctant to monitor and assess performance and evaluate program implementation at least once in five years. In addition, the Malaysian government also tends to approve budgetary allocations to various ministries without assessing performance and achievement, particularly as the opposition is weak (Ibid; 48).

As demonstrated above, there are various techniques and processes involved in performance monitoring and evaluation. However, there are also complexities associated with performance appraisal process as demonstrated in experiences from other countries. The following section examines performance monitoring and evaluation in the context of Botswana.

\section{Performance monitoring and appraisal in Botswana's public sector}

The government of Botswana has since the 1980's introduced new public management systems and techniques to enhance service delivery and improve implementation of public policy and programs. The new initiatives to transform the public service include performance management systems, the balanced score card, process re-engineering, change management and e-government initiatives (Republic of Botswana, 2003). It is worth noting that Botswana inherited a weak administrative structure from the British colonial government in 1966 when the country attained independence. With the discovery of diamonds in the 1970s the government used diamond revenue and invested heavily in building administrative structures, establishing education, health, water, electricity, telecommunication sectors and other infrastructural development projects. The 1980s was therefore a period in the country where many reforms were introduced in order to enhance existing administrative structures and the legislative framework, systems and processes.

According to Hope (1995), many public sector reform initiatives were introduced including re-organisation of the public service and training and localisation in the 1980s 
in order to address problems of uncoordinated efforts and poor policy and program delivery as well as complaints from citizens about poor service delivery. In addition, decentralisation of human resource functions from the Directorate of Public Service Management to government ministries and departments, computerisation of public servants' personnel records formed part of reforms of the 1980s (Republic of Botswana, 2003). Performance and organisational management strategies such as total quality management (TQM), Work Improvement Teams (WITS), Job Evaluation, performance management systems (PMS), revised performance monitoring and appraisal methods, strategic planning and management, balanced score cards (BSC) and process reengineering (BPR) were introduced in public institutions (Republic of Botswana, 2002a) (see table 3 below). These strategies were adopted in order to improve service delivery, performance management, monitoring and appraisal, improve coordination and accountability at individual, team and departmental/ministerial level and enhance morale of public servants. In addition, reforms were aimed at addressing issues of inefficiency and ineffectiveness of public institutions in service delivery to citizens and poor performance in policy and program implementation and monitoring. Table 3 below demonstrates how the public service has evolved over time.

\section{Table 3: Evolution of Public Service in Botswana}

\begin{tabular}{|rl|}
\hline Public Sector Reforms Initiatives \\
\hline 1980s & \\
- & Re-organisation of government ministries and independent departments \\
- & Training and Localisation \\
- Job Evaluation \\
- Productivity Improvement and Work Improvement Teams (WITS) \\
- - Coeding out deadwood \\
- Decentralisation of HR functions \\
- Computerisation of personnel files \\
\hline - P90s \\
- Performance management systems \\
- Pystems thinking, strategic management \\
- Privatisation, out-sourcing, contracting out
\end{tabular}




\begin{tabular}{|rl|}
\hline 2000s & \\
- & Change management \\
- & Balance score card \\
- & Establishment of public-private partnerships \\
- E-government, e-services \\
- Awarding Innovation in the public sector through work improvement teams \\
- Annual public service day celebrations to recognise innovativeness \\
\hline 2015 and beyond \\
Code of ethics \\
Collaborative and net worked government
\end{tabular}

Source: Hope, 1995; Republic of Botswana, 2003 \& 2009; Mpabanga, 2011

\section{Benchmarking performance monitoring and evaluation}

It is worth noting that the reforms that took place in Botswana since the 1980s were as a result of recommendations from various international organisations including the World Bank and consultants from different countries around the world (Republic of Botswana, 2003). The evolution of public sector reforms in Botswana can thus be said to be a mixture of performance management systems and performance monitoring and evaluation tools from different international baskets. For example, the re-structuring of government ministries and departments was a result of a recommendation from consultants from the United Kingdom, the concept of productivity improvement, work improvement teams (WITS) was a recommendation from consultants from Singapore, performance management was recommended by the World Bank, the introduction of contract employment and weeding out a deadwood was an idea borrowed from the Australian and New Zealand civil services (Republic of Botswana, 2003). It could be argued that performance management and performance measurement, monitoring and evaluation tools were imported from outside and adapted to suite the context of Botswana's government institutions. The benchmarking was done through international organisations and consultants who suggested to government to consider adopting multiple reforms to transform public service and educate and train leadership and senior managers in new public management initiatives.

PMS was the first public sector reform concept or tool which introduced the process of strategic thinking and planning in the public service. Prior to performance management systems there were other reform initiatives such organisation and methods 
(O\&M) where government ministries and departments were re-organised, job evaluation, decentralisation of some HR functions, work improvement teams (WITS) in order to promote team work and enhance service delivery (Hope, 1995; Republic of Botswana, 2003).

\section{The Balanced Score Card}

The public sector in Botswana introduced the score card in order to focus on improving efficiency and effectiveness in service delivery and to excel in the areas of financial, customer services, internal processes and leaning and growth. One of the major benefits of using the score card was that the existing performance management system was incorporated into the score card. The idea was to use the score card framework to enhance performance management by for example, using the concept of key results areas (KPA), key performance Indicators (KPI) and targets to set strategic objectives in the basis of a score card framework or perspectives which entail finance, customer, internal processes, learning and growth. Table 6 below demonstrates a score card for the Ministry of Health. The score card uses the four perspectives to measure performance and achievements form customer services to learning and growth. It is worth noting that the balanced score card incorporated the key elements of a performance management system (PMS) which was adopted by the government in 1998 (Republic of Botswana, 2003).

\section{Re-engineering of performance monitoring and evaluation processes}

In order to improve the performance management system and the strategic planning and management process, a business process engineering model was introduced into the public service in the late 1990s and early 2000s (Republic of Botswana, 2003). Reengineering of business process is similar to that of the private sector and public institutions around the globe are continuously re-engineering process in order to reach high levels of effective and efficient in government. The public sector in Botswana has joined global efforts to make public institutions to deliver effective and efficient services by re-engineering systems and processes.

Various processes were re-engineered and service standards established across government departments and ministries. The public service standards are normally displayed at every government ministry and department outlining the expected 
timeframes for service delivery. For example, each department has service delivery standards established after the re-engineering of processes and expected length of time for service delivery are displayed for customers to see they come in any government office request for public services. Some of the positive outcomes of re-engineering of process is for example payment of suppliers which takes only 10 days, the processing of national identity card takes 8-10 days and the application of a national passport takes maximum of 5 days (Republic of Botswana, 2009).

The performance monitoring and evaluation system was re-engineered to focus on strategic areas of management and service delivery, resulting in a revised tool to monitor and evaluate performance at national, ministerial, departmental and individual level. For example, at the national level, the balanced score card was introduced to monitor the financial, customer and processes of service delivery (Republic of Botswana, 2010). At the employee level the monitoring and appraisal tool was re-engineered to be carried more than once a year (Republic of Botswana, 2002a) and the performance reward mechanism was re-engineered to include financial and non-financial rewards (Republic of Botswana, 2002b).

\section{Employee Performance Monitoring and Evaluation}

Public employees were also brought into the strategic planning process to develop individual strategic objectives and goals based on their departmental and ministerial strategic objectives and plans. This planning process was aimed at linking and aligning the ministerial, departmental and employee strategic objectives and performance plans. In other words, the PMS process was used to introduce the strategic planning and management process into government, a management process which is commonly used in the private sector (Armstrong, 2009). The performance management system has led to public institutions developing strategic objectives and plans which were linked and aligned to the national vision which ends in 2016 and the national development planning process (Republic of Botswana, 2009). In addition, the public institution strategic objectives and plans were linked to departmental and individual performance plans. The strategic plans were focused on main objectives tied to the responsibilities and key performance areas and indicators for each Ministry and Department linked to individual plans with the overall aim of delivery effective and efficient service to citizens. 
A study by Longenecker, Frink \& Caldwell (2014:324) of 182 organisations surveyed in the United States of America revealed that 96.2 percent of appraisals are carried out by immediate supervisor, 92.3 percent by one other person and only 20.2 percent of rating forms allowed self-appraisals take place. In relation to employee training only 19.1 per cent of organisations surveyed offered training in the rating process compared to 37.2 percent required training for their managers. The use of information technology in rating was prevalent as the survey revealed that 93.9 per cent of organisations used electronic or web-based rating forms (Ibid; $323 \& 325$ ). In addition, the survey revealed that 72 per cent of organisations conducted annual appraisals, while 23 per cent did semi-annual rating and only 4.9 percent conducted quarterly ratings. Interestingly 24 percent of organisations require informal mid-term performance cycle alignment review session.

In the case of Botswana's public servants, performance reviews were transformed from once a year process to at least bi-annual to quarterly appraisals (Republic of Botswana, 2002b). This was as a result of the performance management system and the strategic management process which required alignment of strategic objectives with performance plans and targets at individual, department, ministerial and national level. The performance appraisal at employee level is reviewed by the immediate supervisor, where rewards of either monetary or developmental in nature are awarded deserving public servants at the end of the review process. The performance based reward system was also introduced which outlines monetary and non-monetary rewards. The use of multi-tier review such as the 360-degree feedback is not common in Botswana, particularly in the public service. However, some government ministries use customer service feed-back rating forms where customer rate the service delivered by a specific government department or unit and these forms are in some cases assessed by effected units/departments to improve service delivery.

\section{Ministerial and Departmental Performance Monitoring and Evaluation}

The public sector in Botswana introduced the score card in order to focus on improving efficiency and effectiveness in service delivery and to excel in the areas of financial, customer services, internal processes and leaning and growth. One of the major benefits of using the score card was that the existing performance management system was incorporated into the score card. The idea was to use the score card framework to 
enhance performance management by for example, using the concept of key result areas (KPA), key performance Indicators (KPI) and targets to set strategic objectives in the basis of a score card framework or perspectives which entail finance, customer, internal processes, learning and growth. Table 6 below demonstrates a score card for the Ministry of Health.

The review of the score card in terms of progress towards the achievements in key performance areas and targets is monitored and evaluated on a monthly basis where all government ministries and independent departments have monthly consultative meetings, for example the ministerial performance improvement committees chaired by the Permanent Secretary (Molale, 2009). Permanent Secretaries play a crucial role in each ministry to monitor and report progress in policy and program implementation contained in the score card. The monitoring and evaluation of implementation of key performance areas contained in the score card is carried out by ministries and departments through annual review meetings where they assess progress and re-align strategic objectives using the financial, customer, process and learning and growth perspectives (see table 5 below).

\section{Performance Monitoring and Evaluation at the National Level}

Performance management and measure has changed at the national level where aspects of the strategic management and the balanced score card approach have been incorporated into the national planning process. The national planning process has over the years advanced to the level of being aligned to the national vision which ends in 2016 (see table 4 below). In addition, the latest national development plan which covers the period 2009 to 2015 has strategic objectives which are linked and aligned to the national strategy which was developed using the four perspectives of a balanced score card (BSC) (Republic Botswana, 2009).

Table 4: Components of the National Development Planning Process in Botswana

\begin{tabular}{|c|}
\hline Vision 2016 \\
\hline The National Development Plan \\
\hline Integrated Development Planning \\
\hline Performance Management System \\
\hline
\end{tabular}


74 Africa's Public Service Delivery \& Performance Review

\begin{tabular}{|c|}
\hline The Balance Score Card \\
\hline Results Based Management \\
\hline Integrated Results Based Budget \\
\hline Integrated Personnel Performance System \\
\hline Performance Based Reward System \\
\hline Integrated Monitoring and Evaluation Systems \\
\hline
\end{tabular}

Source: Republic of Botswana, 2009

It is interesting to note that the scorecard framework was used in the national development planning process (Republic of Botswana, 2009) and the current national development plan is outlined according to the main elements of the score card as demonstrated in the diagram below. In addition, the development plan also uses the integrated development planning model which identifies priorities and development projects and links them to the national budget. This plan is also linked to seven key areas or pillars of the national vision which ends in 2016 (Republic of Botswana, 2009:29). For example, the national plan has ten key results areas, sixteen national goals, ten national development objectives together with key performance indicators and targets. The table below demonstrates a score card for selected national goals, programs and policies.

Table 5: Balanced Score and selected National Development Goals, Projects, Programs and Policies

\begin{tabular}{|l|l|l|}
\hline $\begin{array}{l}\text { Balanced } \\
\text { Score Card }\end{array}$ & $\begin{array}{l}\text { Key Result Areas \& National } \\
\text { Goals }\end{array}$ & Projects, Program \& Policy \\
\hline $\begin{array}{l}\text { Customer } \\
\text { Stakeholder }\end{array}$ & $\begin{array}{l}\text { Visionary Leadership } \\
\text { Governance, value based }\end{array}$ & $\begin{array}{l}\text { Customer satisfaction survey } \\
\text { Political will \& commitment }\end{array}$ \\
\hline Financial & $\begin{array}{l}\text { Financial Management } \\
\text { Result based budgeting }\end{array}$ & $\begin{array}{l}\text { Waste reduction } \\
\text { Privatisation strategy } \\
\text { Accountability by permanent secretaries }\end{array}$ \\
\hline $\begin{array}{l}\text { Internal } \\
\text { Processes }\end{array}$ & $\begin{array}{l}\text { Implementation \& } \\
\text { coordination }\end{array}$ & $\begin{array}{l}\text { Decentralised HR functions } \\
52 \text { service standards published }\end{array}$ \\
\hline
\end{tabular}


Performance Monitoring and Evaluation in Botswana's Public Service 75

\begin{tabular}{|l|l|l|}
\hline & Reduce bureaucracy & $\begin{array}{l}\text { 237 processes re-engineered across } \\
\text { government } \\
\text { Establish private partnerships } \\
\text { Implement ICT policy }\end{array}$ \\
\hline $\begin{array}{l}\text { Learning } \\
\text { and growth }\end{array}$ & $\begin{array}{l}\text { Human Resource } \\
\text { management } \\
\text { HR planning leadership } \\
\text { capacity }\end{array}$ & $\begin{array}{l}\text { HRD strategy } \\
\text { Leadership development } \\
\text { Public service Act } \\
\text { Bi-annual reviews }\end{array}$ \\
\hline
\end{tabular}

Source: Republic of Botswana, 2009; Mpabanga, 2011: 59 \& 160

Performance monitoring and evaluation at the national level is carried out during the mid-term review of the national development plan. The mid-term review is a consultative process where all stakeholders meet after two years to review progress of the five-year national plan. The mid-term review evaluates national development plan in all sectors in terms of progress in implementation and outcomes staring for the seven national vision pillars, the key result area in the particular pillar, the national development goal, policies and programs in that pillar and as well as the review of the performance of the lead ministry and department in terms of policy and program implementation. As shown in the table below, the monitoring of policy and program implementation is supposed to take place throughout the year by responsible ministry (Minister and Permanent Secretary) and department (Director) and public servant responsible to implement policy/program or carry out the duty.

For example, one of the pillars of vision 2016 is to have an informed and educated nation and this translates to a key results area of producing a competitive, productive and knowledge based society (see table 6 below). The national goal would be for the country to have an adequate supply of qualified, productive and competitive human resources and the lead player to facilitate the achievement of this goal would be the Ministry of Education and Skills development (Republic of Botswana, 2009:30). This goal will be reflected in the Ministry of Education's score card categorised into four perspectives of financial, customer, processes and earning and growth and appear as performance objectives, measure, targets and person responsible will be the Permanent Secretary, Director or a senior manager in the ministry. The same performance objectives 
will be translated to public sector employees in the department where their responsibility will be to deliver educational services to citizens.

Table 6: Botswana's Vision 2016 and National Development Goals

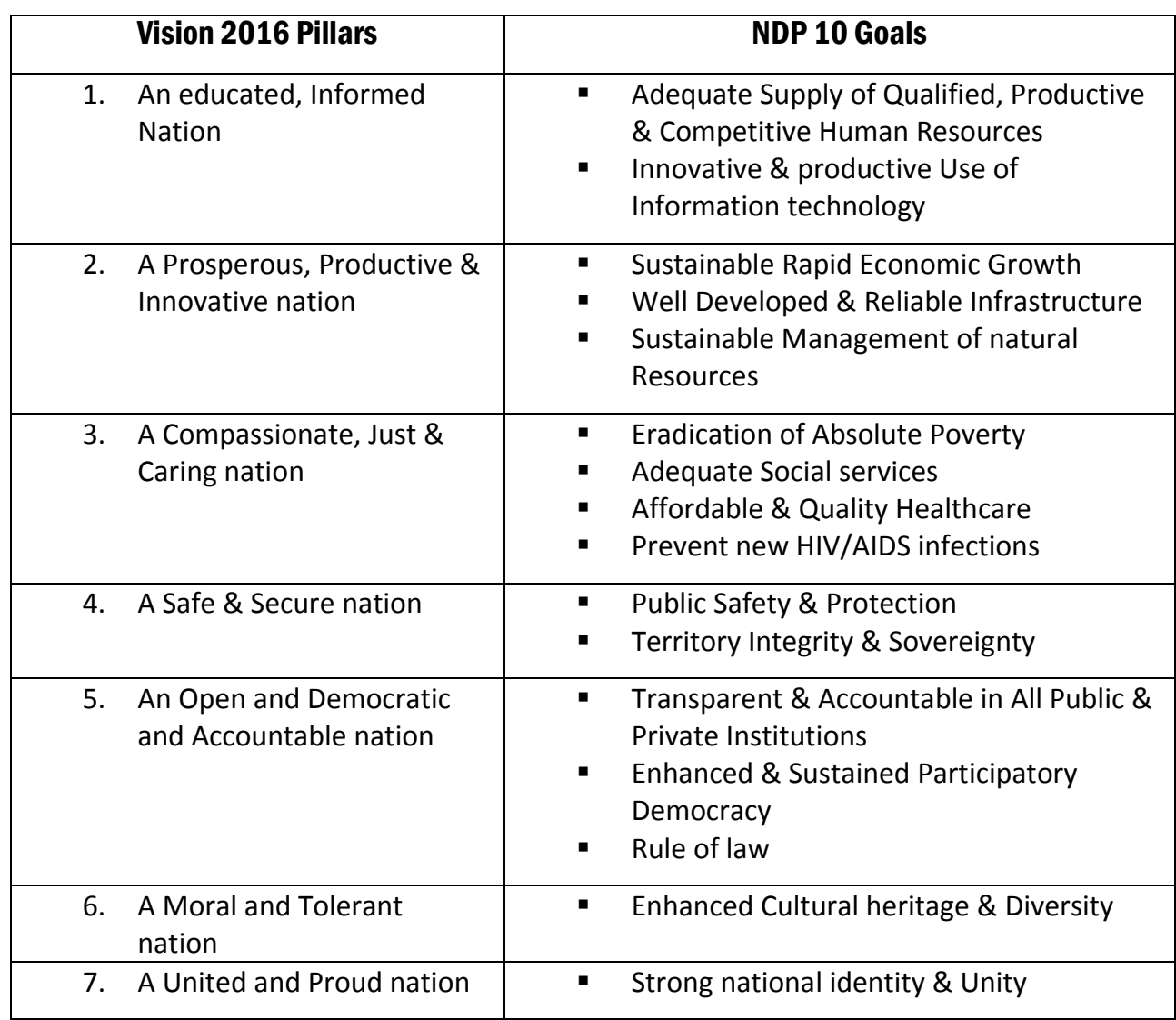

Source: Republic of Botswana, 2009:30.

The above assessment illustrates performance monitoring at the ministerial level which takes place on a monthly basis through consultative meetings while monitoring of individual performance is expected to be a regular occurrence carried out by their immediate supervisor. The evaluation or appraisal of individual performance is carried out on a quarterly basis while the evaluation of ministry's performance is conducted once a year. 
Performance Monitoring and Evaluation in Botswana's Public Service 77

\section{Performance Reward}

It is worth noting the PMS process was accompanied by the review and introduction of a new performance appraisal system which was changed from a once a year process to at least two times a year. The performance reward system was also revised to incorporate aspects of intrinsic and extrinsic incentives entailing financial and non-financial rewards. The new performance based reward system (PBRS) system includes financial rewards in terms of salary increase, promotion for best performers as well as non-financial rewards such as an award of certificates, lunch with the Director (Republic of Botswana, 2003). Supervisors can recommend training and development for employee to improve on performance weaknesses identified during the appraisal process. Annual public service day celebrations are another mode established to reward and motivate public servants for outstanding performance and innovativeness in service delivery. The government also evaluates performance of ministries annually and ministries are ranked according to performance.

Efforts to enhance performance and motivate employees to deliver services to citizens have had positive and disappointing outcomes. Some government institutions continue to struggle in improving service delivery to meet expected objectives and established values and standards. Evidence from a study on reward system in Botswana revealed that objectives of the performance reward system lacked goal clarity, performance targets, customer focus, employee role allocation and this was not in line with the goal setting theory (Kealisitse et al., 2013:48). The following section identifies and assesses some achievements regarding the implementing of performance monitoring and evaluation techniques in Botswana's public service and examines appraisal problems.

\section{Results and Discussion}

Performance monitoring and evaluation in Botswana: Achievements

\section{Commitment and Support for Reforms}

One of the major factors contributing to achievements in Botswana government introducing performance management and appraisal systems was the political and leadership commitment, support and willingness to reform the public service. A top- 
down approach was used to introduce reforms where extensive sensitisation, education and training of leadership and senior management was conducted to appreciate and embrace change and adopt new ways of managing the public service where citizens are viewed and valued as customers. Education and training of leadership and senior managers enhanced commitment and support for reforms.

\section{Technical Factors}

As evident form the documented analysis (Republic of Botswana, 2003 \& 2009; Mpabanga, 2011), one of the outcomes of reforming the public sector was the development and design of performance management systems, the use of the balanced score card and re-engineering of processes. These reforms resulted in establishment of clearly defined strategic plans, objectives, development of key performance and results areas as well as setting of targets and assigning persons responsible to each targets. The application of four perspectives of the score card enhanced performance monitoring and evaluation at individual, departmental/ministerial and national level. This achievement was as a result of willingness, support and commitment of leadership and embracing public service transformation through change and strategic planning. In addition, reforming the public service has also results in the establishment of very good public policy formulation and administration systems and processes as well as development of one of the best legislative and governance structures in the continent.

\section{Benchmarking Performance Management and appraisal}

As mentioned earlier in the paper, Botswana government benchmarked reforms with other countries, with the assistance of the World Bank and international organisations' recommendations to transform the public service. For example, the performance management frameworks and other reforms were adopted from countries such as USA (balanced score card), United Kingdom and Australia (PMS), New Zealand (contract employment of Permanent Secretaries) and Singapore (work improvement teams) (Halachmi, 2002; Zoe \& McGurie, 2004; Hawk, 2012). Other countries in Asia such as Malaysia (Siddiquee, 2010) and Africa adopted and benchmarked their reforms for example Kenya (Marwa \& Zairi, 2009), and Eritrea (Ghebregiorgis \& Karsten, 2007). Benchmarking with developed countries has facilitated Botswana to adopt and design 
performance management systems that have been tried elsewhere although their impact has not generated expected results.

\section{Problems with Performance Monitoring and Evaluation}

\section{Lack of Appraisal Skills}

As mentioned above performance appraisal can be a complex and stressful process for managers and employees. Problems may arise when managers and employees are not given the necessary training, appropriate guidance and support by HR department to conduct effective performance reviews. Some of the appraisal problems include inconsistency in rating, unclear performance standards which may lead to subjectivity, leniency or strictness in rating and biasness based on personalities or traits of employees. In some cases, rating for some employees particularly best performers can be very low leading to demotivation especially if rated average and yet employees consider themselves high performers. Most of these problems are eminent where managers and supervisors lack appraisal skills and in some cases are not sure about what they are doing. High ratings of individual in some case may not correspond to departmental/ministerial ratings which would be low compared to individual rating. This could be a result of biasness and favouritism in rating where non-performing friends or allies are rated high and poor performance is rewarded at the expense of high performers. This can contribute to negative attitude towards work and under performance. As observed in (Kealisitse et al., 2013:49) inadequately designed performance objectives hinders successful implementation of pay for performance such as performance based reward system.

Some managers may have problems giving constructive criticism and regular feedback and communicate effectively with employees when it is time for performance review. As stated by Siddiquee (2010) the culture in developing countries is avoidance of criticism at all levels especially from superiors whom subordinates are respected and junior officers would not dare question their authority (high power distance and uncertainty avoidance). As pointed out by Nel et al., 2011:420) training of supervisors in the performance appraisal process for example in setting of performance standards, giving constructive criticism and motivating employees to be a better person would enhance appraisal outcome. Armstrong (2009:638) posits that an e-reward study 
conducted in 2005 revealed that $88 \%$ of line managers did not have the skills required, $84 \%$ of managers did not discriminate when assessing performance while $74 \%$ were reluctant to conduct performance review.

\section{Poor Supervisory Skills}

One of the major roles of line managers and supervisors is to ensure that employees under their direct supervision perform their tasks according to their job descriptions and individual performance plans. The role of the supervisor is to support and guide employees to identify, prepare and achieve objectives set in performance plans in alignment with the organisation. As mentioned earlier, supervisors' responsibility is to regularly review performance and give constructive feedback to subordinates in order to motivate them achieve goals and encourage them to perform where there is room for improvement (Nel et al., 2011:420). Line managers should be made accountable for performance of their employees and act on poor performance, monitor and review daily activities and take corrective action including reprimanding and dismissing an employee who consistently under-performs. As pointed out by Nel et al., 2011:421) characteristics of high performing corporations include promoting a true believe that vision will be a success, promote pride in employees to be part of the organisation and celebrate single person's success. Poor supervisory skills and uninspiring supervisors especially in performance monitoring and review are some of the factors that contribute to subordinates not able to perform daily tasks and only get feedback during performance reviews.

\section{Performance and Effort}

One of the major challenges of reforms and their ability to enhance performance monitoring and evaluation lies in lack of training at junior level on how to use PMS and the score card frameworks to monitor own performance and enhance policy and program implementation. In most cases public servants especially at lower level develop performance indicators and targets skewed towards financial rewards and plans that are easy to achieve without linkages to organisation results and outcomes. This is the case despite the fact that departments and ministries have well established key performance and results areas and there remains difficulty in aligning and linking their key performance areas with policy and program implementation outcomes. One of the 
contributing factors is limited training at junior level and lack of knowledge to link effort, performance and reward (Taylor \& Taylor, 2011). This is where efforts should be made by HR departments to train supervisors and junior officers to redirect their motivation to include an inspiration to serve the public with diligence.

\section{Poor Working Conditions and Poor Work Ethic}

Another factor contribution to limited success for reforms to enhance HR in the public sector is the tendency to avoid criticism during the appraisal process for not achieving targets as planned. In addition, employees tend to set easy targets that would enhance chances for a financial reward as opposed to a developmental reward due to the need to improve their livelihood. Salaries and wages or the working conditions in the public service are not as attractive as in the private sector. To compensate for the difference some public servants especially at junior level (and those motivated by extrinsic rewards (Taylor \& Taylor, 2011) would tend to equate pay with the amount of work done and would not go an extra mile to deliver quality service to the public. This also contributes to a negative attitude towards work and a poor work ethic (Lesemela, 2014). The public service in Botswana continues to be marked by poor performance monitoring and service delivery in some public sector institutions. For example, the public health sector is overwhelmed by public complaints for poor quality of service in hospitals, shortage of medication and poor care of patients from medical personnel. The education system is also marked by complaints for poor results in primary and secondary schools due partly to low motivation of teachers due to poor conditions of service. Protracted poor conditions of service resulted in the longest public servants strike in 2011 which lasted for a month (Ndlovu, 2011). As pointed out by Marobela (2008:431) reforms have not realised the intended objectives, improving performance and still remains the 'holy grail' of the reinvented governments.

\section{Lack of Monitoring and Evaluation Skills}

Systems and structures to regularly monitor and evaluate performance have been established when public sector reforms were introduced particularly with the advent of performance management systems and the score card. In addition, privatisation and outsourcing of non-essential government services were introduced in order to make 
government lean and public servants to focus on core services related to programs and policy implementation. These reforms were introduced so that government can concentrate on implementing projects, programs and policy in the health, education, transport, construction and service sector. However, at the national level, project implementation, monitoring and evaluation remains a challenge in government, for instance delays in project completion (cost overruns), dilapidated public buildings such as schools, hospitals, roads and expansive equipment due to lack of maintenance (maintenance not included during the budgetary process). Most public servants responsible for project monitoring and implementation complain of lack of skills and training in project implementation, monitoring and evaluation hence poor monitoring and evaluation of public programs and projects. Botswana is not the only country struggling with public sector reforms aimed at enhancing performance management and evaluation. Reforms related to performance management and evaluation have had mixed outcomes in developed countries such as the United Kingdom, United States of America, Australia, Germany and developing countries such as Kenya, Eritrea and Malaysia. Governments in developed and developing countries are continuously striving to perfect their performance management systems through regular reviews and assessments.

At the employee level, there is general lack of knowledge in the performance management and appraisal skills. Although reforms were introduced such as performance management and appraisal system and the score card to enhance monitoring and evaluation of performance, there is general lack of skills by line managers on how to conduct an appraisal interview. Line managers lack skills and competencies on how to give constructive feedback and monitor performance throughout the year (Mpabanga, 2011). The next section suggests approaches to enhance performance appraisal and monitoring system.

\section{Suggestions to improve existing performance monitoring and evaluation in Botswana's public service}

Training and Development to enhance performance Monitoring and evaluation Skills

The paper suggests training of managers in giving feedback on performance, the use of multi-tier appraisal method where all who come into contact with the employee, 
department and ministry give feedback on performance, training of employees to acknowledge the link between effort, performance and job satisfaction. As pointed out by Siddiquee (2010:51) at times the success of reforms is affected by the death of initial enthusiasm when the reforms were first introduced, and suggest that managing for results requires development of capacity and skills of all those involved, including change in managerial attitudes, work habits and organisational culture that emphasises performance and results.

Rowland \& Hall (2013:204) suggest designing mentoring schemes to address the paradox associated with appraisals. They believe that a developmental-led appraisal system would enhance employee engagement, commitment and sustained discretionary effort. As concluded by Rowland and Hall, 'perceptions of inequity have a powerful impact on commitment and performance' (Ibid; 204) and if organisations want to be competitive they should develop sustainable strategies that are responsive in an increasingly changing turbulent environment. Training and development of supervisors would entail mentoring, coaching, simulation exercises so that supervisors appreciate and work on their strengths and weaknesses and strive to be superior line managers by closely monitoring performance, give constructive feedback and acting on under performance.

\section{Enhance Motivation}

Motivation in the public service could be enhanced by improving the conditions of service, especially for employees at the lower ranks of public service. Employees engaged in administrative and clerical work are generally not happy with their conditions of service particularly pay, employee welfare and benefits. Rewarding and recognising good performers and high flyers through consistent and fair appraisal system, where managers and supervisors are trained and educated to conduct the appraisal process fairly and consistency would enhance performance reviews.

\section{Multi Rater-Upward Appraisal}

AS pointed out by Prowse \& Prowse (2009:69) the use of performance pay in public and private organisations linked to appraisal does not always improved organisational performance and may lead to reduced motivation. The suggest using a multi rater upward appraisal tool such as the 360 degree methods to minimise subjectivity in the performance monitoring and evaluation process, where feedback is appraised rather than 
judging performance (Prowse \& Prowse, 2009:72). They argue that employee performance appraisal and critiques have failed to suggest an alternative (Prowse \& Prowse, 2009:75). Kealisitse et al., (2013:49) suggest training of managers and employees to set customer focused objectives and allow external evaluation of customers' experience with service outcomes. As show in the diagram below performance management can be enhanced through a developmental led approach where training and coaching are key elements of the appraisal process.

\section{Figure 6: A performance management cycle}

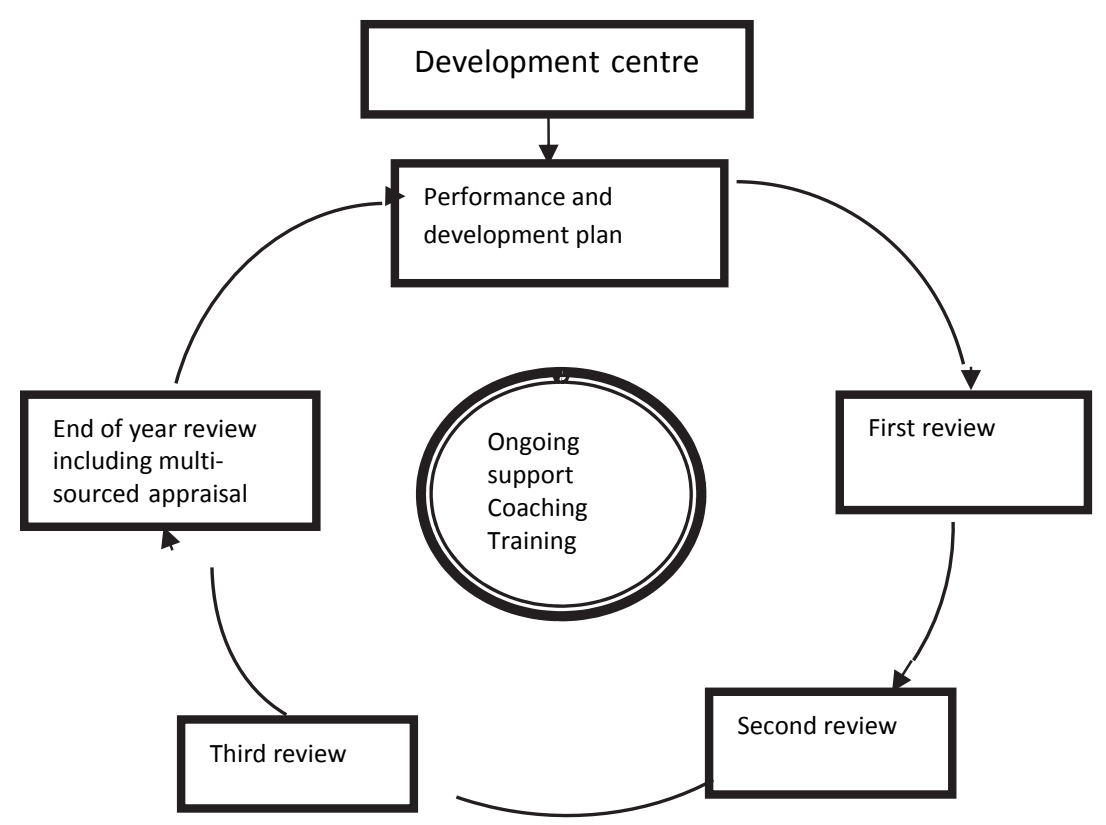

Source: Bratton \& Gold, 2007:280.

This paper has reviewed performance monitoring and evaluation in Botswana by examining performance appraisal at employee, ministerial and national level. The paper argues that performance monitoring and evaluation starts at the employee level and the ability to effectively implement government policy and programs is influenced by the motivation and effort exerted by each and every public servant with the drive to deliver effective and efficient public service to citizens. As the literature review has suggested, 
governments around the globe have used a variety of tools to monitor and evaluate performance in order to improve performance in public policy and program implementation. Multiple techniques are suggested in the literature including the use of performance management systems, balanced score cards, and many other tools to enhance performance monitoring and reviews such as behavioural and objective methods, category, narrative and comparison methods as well as 360 degree or multitier appraisals.

The government of Botswana has also adopted these tools, particularly the performance management system and the balanced score card in order to enhance performance of public servants including re-engineered performance appraisal and monitoring system. However, these tools have not produced expected results. One of the positive outcomes of adopting performance management systems and the score cards are noticeable at the strategic level of the public service. There is wide evidence of clearly defined and aligned vision, value and mission statements, strategic plans and objectives, key performance areas and indicators linked to results, targets and those responsible and accountable for their achievement (see table $5 \& 6$ ). As evident in the tenth national development plan of Botswana, performance monitoring and evaluation has over the years, been identified as one of the major weaknesses in the performance management system and in the effective and efficient implementation of policy and programs (Republic of Botswana, 2003). This includes the existing employee appraisal system which has failed to help civil servants deliver services and results through reengineered systems of monitoring and evaluating performance.

However, the use of performance management and the score card to enhance performance have had a positive outcome at the strategic level but not produced the desired results at lower levels of the public service. As pointed by various authors from the literature review, performance monitoring and evaluation is riddled with many problems including lack of training and poor interpersonal skills of managers, criticisms associated with employee appraisals for example subjectivity, no evidence to link performance pay and improved organisational effectiveness. The philosophy or perspective to performance appraisal and monitoring has an impact on its effectiveness as advocated by the various conceptual frameworks that could be adopted to form the basis of a performance monitoring and evaluation system. A system based on traditional-rational perspective of a systematic and planned approach that is designed to 
control the behaviour and attitudes of employees is less likely to have succeeded than a due process model (Thurston Jr. \& McNall, 2010). Bratton \& Gold (2007) advocate for developmental and transformational models to harnesses people's potential for future development which focuses on transforming behaviour as employees perform and master tasks. Whereas Rowland \& Hall (2013) feel that appraisals with a perception of inequity can impact on commitment and performance of employees, hence they suggested an appraisal system should accommodate diversity and incorporate elements of organisational justice and a wider ethical framework.

In the case of Botswana, performance monitoring and evaluation could be enhanced by applying the organisational justice theory based on the due process model in addition to using the developmental approach and the transformation framework. The objective will be, as pointed out by Rowland \& Hall (2013) to instil a sense of commitment and pride in work, and change the attitude at middle to lower levels of the public service, particularly immediate supervisors and employees doing administrative and clerical tasks (front desk/service centre staff). Using this approach would contribute to building their knowledge, capabilities and skills to help them realise the importance of linking performance, effort to outcomes and not only be motivated by financial rewards associated with performance review. 
Figure 7: Performance Monitoring and Evaluation Developmental Model for Botswana's Public Service

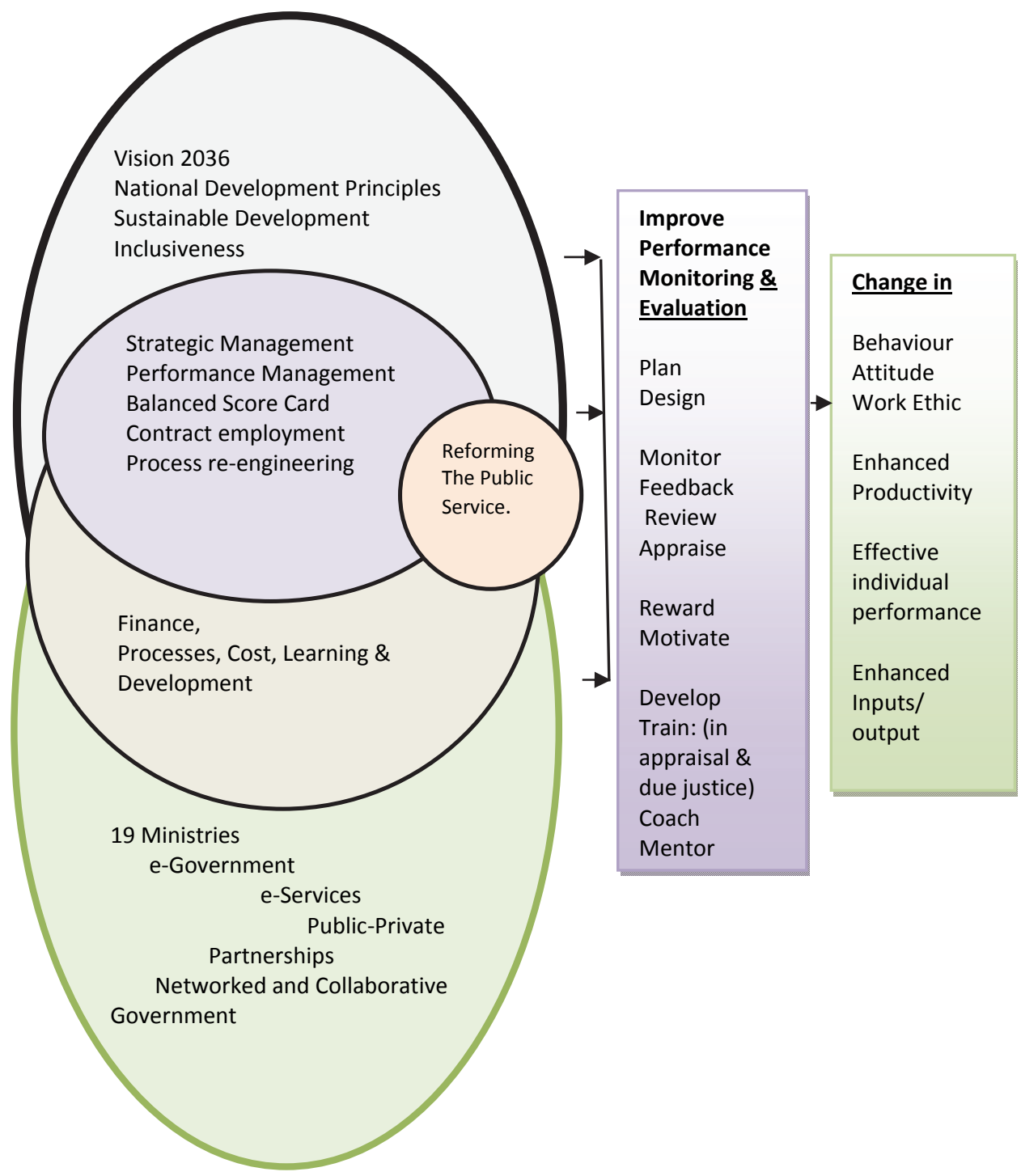

As shown in figure 7 above, an appropriate model for Botswana would be a developmental approach to performance monitoring and evaluation where mentoring and couching are the key factors to build capacity of line managers, supervisors and 
employees. The developmental process commences at the national level where the national vision 2036 is aligned with the national development principles of inclusive and sustainable economic development and growth (see figure 7). In order to achieve sustainable economic development, national development goals should be aligned with continued efforts to reform and transform the public service through the strategic management and planning process coupled with moving towards a net-worked and collaborative government. A net-worked and collaborative government calls for the inclusiveness of all stakeholders in the public policy and program development and delivery process as well as in efforts to enhance productivity through establishment of partnerships and collaboration with various stakeholders in the country. A developmental approach would also build capacity at national level in public policy and program monitoring and evaluation.

\section{Recommendations}

Firstly, the performance monitoring and evaluation would be improved by using a developmental and the transformational approach where emphasis would be on training and development to build capacity of managers and employees in performance monitoring and evaluation. A developmental approach would enhance managers on ability to give constructive feedback and develop their competencies to prepare adequately for performance review meetings. Regular feedback through continuous monitoring of performance would help immediately identify areas for continuous improvement.

Secondly, changing behaviour and attitudes of public servants, particularly line managers/supervisors and employees towards work and would make them realise the strategic importance of having a positive attitude towards performance appraisal and monitoring for enhance service delivery.

Thirdly, designing intrinsic and extrinsic motivational packages, particularly for civil servants at the lower cadre and those directly serving the public, as well as improving their working conditions would help instil a sense of pride in performing and achieving daily tasks. This would also develop resilience in serving the public and contribute to a positive work ethic and improve productivity. As pointed by Nel et al., (2011) this could be achieved through counselling of both supervisors and employees in order to explore underlying factors that contribute to poor work ethic and low productivity in the public 
service in Botswana. A developmental approach through mentoring and coaching would enhance the capacity and ability of line managers to manage their employees, while employees manage their daily responsibilities.

Fourthly, the existing performance monitoring and evaluation system could be enhanced by using a multi-tier upward and sideways performance monitoring and evaluation techniques to improve perceptions of fairness in the appraisal system.

Lastly, incorporating the organisational justice perspective would contribute to enhancement of the existing performance monitoring and evaluation process as this would help line managers to appropriately monitor, evaluate and reward performance and help employees commit to work and develop a sense of pride in their work.

\section{Conclusion}

This paper has explored performance monitoring and evaluation systems achievements and problems associated with performance appraisals in Botswana's public service at the employee, departmental/ministerial and national levels through secondary data analysis. The paper has identified some achievements which were made possible by a committed and supportive leadership, which contributed to a well-established performance management and review system with clearly defined mission, vision and value statements, strategic objectives and plans which are linked to the national development planning process. Some of the problems with the performance monitoring and review process include lack of training in appraisal, lack of supervision, poor supervisory skills, poor working conditions which contribute to poor work ethic and low morale. Enhancing performance monitoring and review would improve motivation to perform resulting in better service delivery to the nation and ultimately improving policy and program implementation. The paper suggests a developmental-led approach to improve the existing performance monitoring and evaluation in Botswana's public service. The existing review system would be enhanced by using a developmental-led model which includes counselling (Nel et al., 2011) and encompasses capacity building in performance monitoring and review, cultivating a culture of valuing serving the public (intrinsic motivation to serve the public (Taylor \& Taylor, 2011) as opposed to extrinsic (mostly financial) reward. Using a multi-tier appraisal system incorporating elements of the organisational justice model (Thurston Jr. \& McNall, 2010) would minimise dilemmas associated with appraisals. As this paper is based on secondary data, future research 
should strive to apply quantitative and qualitative research design and collect empirical data that would unlock the challenges and myths of performance monitoring and evaluation and suggest a robust model that would enhance application of performance monitoring and evaluation frameworks that would contribute to the successful implementation of public policies and programs because of an enhanced morale of civil servants.

\section{List of References}

- Armstrong, M. (2009). Armstrong's Handbook of Human Resource Management. 11 th Edition. London: Kogan Page.

- Ahmed, I., Sultana, I., Paul S, K., \& Azeem, A. (2013). Employee performance evaluation: a fussy approach. International Journal of Productivity and Performance Management, 62(7), 718-734 Available from: www.emeraldinsight.com1741.0401.htm , [Accessed on 3 November 2014].

- Awases, M.H., Bezuidenhout, M.C. \& Roos, J.H., (2013). 'Factors affecting the performance of professional nurses in Namibia', Curationis 36(1), Art. \#108, 1-8. Available from: www. http://dx.doi.org/10.4102/ curationis.v36i1.108, [Accessed on 7 April 2016].

- Bratton, J. and Gold, J. (2007). Human Resource Management, Palgrave.

- Halachmi, A., (2002). Performance measurement and government productivity, Work Study, 51(2), 63-73 Available from: www.emeraldinsight.com/0043-8022.htm , [Accessed on 3 November 2014].

- Hawke, L. (2012). Australian public sector performance management: successes or stagnation, International Journal of Productivity and Performance Management, 61(3), 310 328 Available from: www.emeraldinsight.com/1741-0401.htm , [Accessed on 3 November 2014].

- Hope, K, R. (1995). Managing the public sector in Botswana, International Journal of Public sector management, 8(6), 51-62. Available from: www.emeraldinsight.com/, [Accessed on 3 November 2014].

- Kealesitse, B., O'Mahony, B., Lioyd, B., \& Michael, W., and Polonsky, J. (2013). Developing customer-focused public sector reward schemes: evidence from the Botswana 
government's performance based reward system (PBRS). International Journal of Public Sector management, 26(1), 33-55 Available from: www.emeraldinsight.com/ , [Accessed 3 October 2014].

- Knippen, J. T., \& Green, T, B. (1995). Responding to an unfair appraisal, Management Development Review, 8 (5), p.29-31 Available from: www.emeraldinsight.com.htm [Accessed on 3 November 2014].

- Kaplan, R. S., \& Norton, D. P. (1996). Using the balance score card as a strategic management system, In Olve, Roy, J. \& Wetter, M. 2000. Performance drivers: A practical guide to using the balance score card. West Sussex: John Wiley and Sons.

- Lesemela, K. (2014). BNPC strives to improve work ethics. Mmegi Business Reporter (on line) $11^{\text {th }}$ September 2014: Available from http://www.mmegi.bw, [Accessed 19 January 2015].

- Longenecker, C.O., Fink, L. S., \& Caldwell, S. (2014). Current U.S. trends in formal performance appraisal: practices and opportunities- part one. Industrial and Commercial Training. 46(6), 321-326 Available from: www.emeraldinsight.com, [Accessed on 3 November 2014].

- Marobela, M. (2008). New public management and the corporatization of the public sector in peripheral capitalist countries, international Journal of Social Economics, 35(6), 423-434 Available from: www.emeraldinsight.com/0306-8293.htm , [Accessed on 3 November 2014].

- Marwa, S. M., \& Zairi, M. (2009). In pursuit of performance-oriented civil service reforms (CSRs): A Kenyan perspective. Measuring Business Excellence, 13(2), 34-43 Available from: www.emeraldinsight.com, [Accessed on 3 November 2014].

- Mathis, L. R., \& Jackson, J. H. (2000). Human Resource Management, South Western Thompson Learning.

- Molale, E. (2009). Managing and measuring performance in the public service in Botswana, paper presented at the $6^{\text {th }}$ Commonwealth forum for Heads of State.

- Mpabanga, D. 2011. Accountability and Performance Measurement in Selected Government Institutions in Botswana, In D, Greiling, A. Halachni \& R. Schauer (Eds), $9^{\text {th }}$ International Symposium on Public Sector Management, Johannes Kepler University, Linz, Trauner, Austria.

- Ndlovu, T. (2011). News blackout on civil service strike. Sunday Standard (on line) $3^{\text {rd }}$ April 2011: Available from: http://www.sundaystandard.info , [Accessed 19 January 2015]. 
- Nel, P., Werner, A., Poisat, P., Sono, T., du Plessis, A., \& Ngalo, O. (2011). Human Resource Management, Oxford university press.

- Prowse, P., and Prowes, J. (2009). The dilemma of performance appraisal, Measuring Business Excellence, 13(4), 69-77. Available from: www.emeraldinsight.com, [Accessed on 3 November 2014].

- Radebe, P., Q. (2015). Managers' perceptions of the performance appraisal system in the local municipalities of Gauteng Province in South Africa. Mediterranean journal of Social Sciences. $\quad 6 \quad$ (1) $\quad$ S1. 175-182. Available from: www.mcser.org/journal/index.php/mjss/article/view/5525/5329, [Accessed on 7 April 2016].

- Radnor, Z., \& McGuire, M. (2004). Performance management in the public sector: fact or fiction? International Journal of Productivity and Performance Management, 53(3), 245-260 Available from: www.emeraldinsight.com/1741.0401.htm, [Accessed on 3 November 2014].

- Republic of Botswana, (2003). national development plan 9, ministry of finance and development planning. Gaborone: Government printer.

- Republic of Botswana, (2009). national development plan 10, ministry of finance and development planning. Gaborone: Government printer.

- Republic of Botswana, (2002a). Performance Management Systems (PMS), Directorate of Public Service Management (DPSM). Gaborone: Government printer.

- Republic of Botswana, (2002b). Performance Based Reward Systems (PBRS), Directorate of Public Service Management (DPSM). Gaborone: Government printer.

- Rowland, C. A., \& Hall, R. D. (2013). Perceived unfairness in appraisal: engagement and sustainable organisational performance, EuroMed Journal of Business, 8(3), 195-208 Available from: www.emeraldinsight.com/1450-2194.htm, [Accessed on 3 November 2014].

- Siddiquee, N. A. (2010). Managing for results: lessons from public management reform in Malaysia, International Journal of Public Sector Management, 23(1), 38-53 Available from: www.emeraldinsight.com/0951-3558.htm, [Accessed on 3 November 2014].

- Taylor, J., \& Taylor, R. (2011). Working hard for more money or working hard to make a difference? Efficiency wages, public service motivation and effort. Review of public Personnel Management. 31(1), 67-86. Available from: http://ras.sagepub.com/content., [Accessed 17 September 2014]. 
Performance Monitoring and Evaluation in Botswana's Public Service 93

- Thurston Jr., P. W., \& McNall, L. (2010) Justice perceptions of performance appraisal practices. Journal of Management Psychology. 25(3), 201-228. Available from: www.emeraldinsight.com/0268-3946.htm, [Accessed 6 April 2016].

AUTHOR'S CONTACT:

MPABANGA, Dorothy

University of Botswana Email: MPABANGA@mopipi.ub.bw 